\title{
Open-Inquiry Course Design in the Public Policy Classroom
}

Andrew Pennock, University of Virginia

ABSTRACT This article describes a variant of experiential course design-open inquiry-that has learning-how-to-learn (or metacognition about learning) as a primary course goal. In open-inquiry designs, students first choose the problems that they will study during the course. They then co-create each class period as the semester progresses. They recognize deficiencies in their own content knowledge, skills, and learning processes and take actions to remedy them. By reflecting on their successes and failures, students practice the skill of self-directed learning. This process of metacognitive reflection is a crucial skill that they will need when they face novel problems after graduation. In open-inquiry courses, students have produced high-quality work by learning about substantive policy areas that they choose to study, developing the policy skills that they deem important, and growing in their understanding about how they learn effectively.

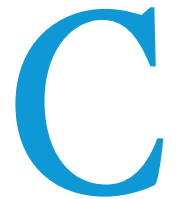

ourses most often are structured by an instructor who decides the topics and conveys expert knowledge to students through class activities including lectures, example problems, and discussion. When instructors engage evidence-based teaching practices, student learning is profound. For example, classes that feature active engagement substantially increase student learning (Freeman et al. 2014). The growing consensus around what constitutes evidence-based teaching urges instructors to think systematically about how both teaching and learning must be at the heart of course design (Palmer, Streifer, and Williams-Duncan 2016). ${ }^{1}$

Evidence from this growing teaching and learning literature highlights the importance of students understanding not simply what they are learning but also how they are learning it. Various learning frameworks name this skill as "learning how to learn" (Fink 2013) or metacognition (Tolman and Kremling 2016). When students think about their learning process (i.e., metacognition), their learning increases (Hacker, Dunlosky, and Graesser 1998; Kolb 1984; Tobias and Everson 2009).

When metacognition is included as a learning goal, students will more effectively learn and retain the core skills of our degree programs. When they understand how they are learning, they are more likely to score higher on exams and take learning further into the future. For example, incorporating metacognitive strategies

Andrew Pennock (D) is assistant professor in the Batten School of Leadership and Public Policy at the University of Virginia. He can be reached at andrew.pennock@virginia.edu. into quantitative classes pays dividends for our students, much like it does for those taking quantitative classes in other contexts (Pugalee 2001; Schoenfeld 1992).

Curricula and courses can and should teach students explicitly how to learn, not only for the short-term payoff in retaining specific knowledge but also because when students enter their career, they will be asked to learn about novel policy problems and learn the new skills needed to address them. Our programs should prepare students not only to understand current problems but also how to understand new ones.

If learning how to learn is an important skill, how can we design courses that help students become proficient in this skill? One pedagogical strategy-open inquiry-places learning how to learn at the core of the course design. In open-inquiry designs, students are in charge of choosing which topics they study and how they study them. Students must explain and defend their choices about what they learn and how they learn, placing metacognition firmly at the core of each class period. This article describes open-inquiry course design: what it is, why it is a good fit for a policy classroom, what professors who are interested in using open-inquiry course designs need to consider when using this method, an example course implementing open-inquiry course design, and evidence of student learning.

\section{WHAT IS OPEN INQUIRY?}

Open-inquiry course design is an experiential course design that is distinctive in the degree to which a professor challenges students to take agency over their learning. The professor puts students in charge of two central aspects of the course. First, students choose 
the topics that they want to study during the semester, subject to certain criteria (e.g., issue area, geographic scope, and accessibility of data). Second, as students begin to explore the topics they have chosen, they co-design each class period throughout the semester. Because the professor cedes this control and authority to students, they are required to step into the design space. They must recognize deficiencies in their own content knowledge, skills, and learning processes. They then must take active steps to remedy their deficiencies by co-designing the class periods. Each
McInerney and Adshead 2013). Sometimes described as "sheltered workshops," these courses focus on one problem and then walk students through a set of defined steps designed to help them learn about and address the problem (Cooley and Pennock 2015; Vining and Weimer 2002). Many capstone courses are suitable for this purpose.

In contrast to other experiential course designs, open inquiry has several distinct differences that leverage student learning in both substantive knowledge and technical skills as well as across

\section{In open-inquiry designs, students are in charge of choosing which topics they study and how they study them. Students must explain and defend their choices about what they learn and how they learn, placing metacognition firmly at the core of each class period.}

week, students must articulate what they know and, more important, what they need to know to themselves, their peers, and their professor. Once the students articulate the limits of their skills and knowledge, they work together with the professor to create and schedule class activities, identify and select readings, and bring in guest speakers to remedy any gaps.

The unique agency that students are given in this course design distinguishes open-inquiry classes from other prominent course designs (figure 1). Open-inquiry courses do share many common elements with other experiential course designs. In experiential designs, students learn through examining processes as well as final work products (Williamson and Gregory 2010). They understand and assimilate their learning through structured reflection exercises that engage the whole person (Blount 2006; Cross and Grant 2006). However, compared to experiential-learning designs such as service learning and internships, the open-inquiry design is more course focused because it keeps the locus of the project inside the traditional classroom. Students are learning primarily through class activities and then processing them in class rather than doing work for an external organization and then processing that work in the course. The open-inquiry structure gives students more autonomy over their questions and activities.

Open-inquiry course designs also share many of the same features as problem- and client-based learning designs. All three designs are centered explicitly on problems that then drive what students study in the course. When executed well, these courses are effective in increasing student learning about substantive content and process (Amyot 2014; Major and Palmer 2001; other important dimensions. Giving students agency and responsibility for choosing their projects explicitly challenges them to select those that reflect their values. Student responsibility for creating the weekly class content places them in direct conversation with their own understanding about how they learn. These differences challenge them to develop into the competent professionals that we hope they will become.

\section{HOW DOES OPEN INQUIRY TIE INTO THEORIES OF TEACHING AND LEARNING?}

The open-inquiry course design generates the high-level, integrated, growth-oriented learning lauded by several teaching and learning theories. The best known of these is Bloom's taxonomy (figure 2) (Airasian, Anderson, and Krathwohl 2000; Bloom 1956). In open-inquiry course designs, like many experiential courses, learning occurs from the foundation to the highest level. Students learn and understand facts and concepts about the policy problem. They then apply their knowledge to new situations and use it to analyze the policy problem, evaluate potential solutions, and create policy documents to communicate to policy makers (Bardach and Patashnik 2015; Pennock 2011; 2018).

Whereas Bloom's (1956) taxonomy affirms why experiential classes create so much student learning in graduate curricula, Fink's (2013) integrated theory of learning shows why openinquiry classes excel (figure 3). Fink's framework broadens the common reading of Bloom's framework to be more wholistic and integrative for students. Knowledge and application are still important; however, for learning to transform students, course

Figure 1

The Didactic to Experiential Spectrum of Pedagogical Strategies

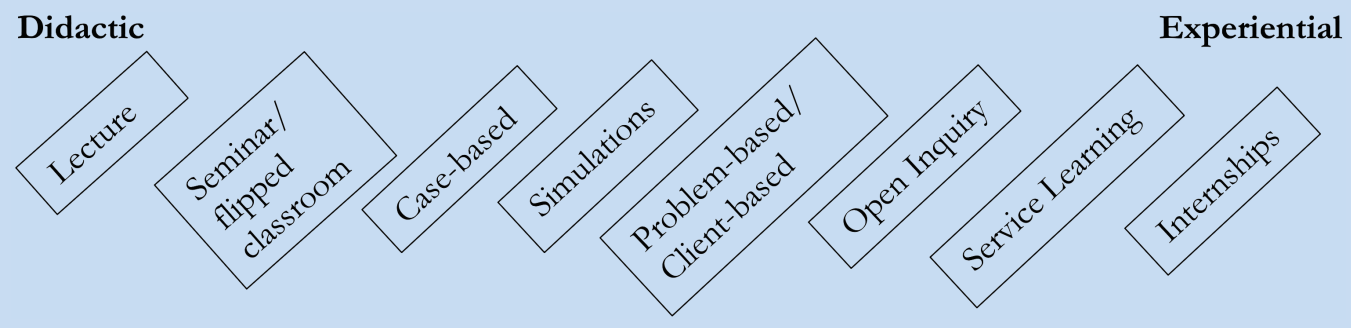




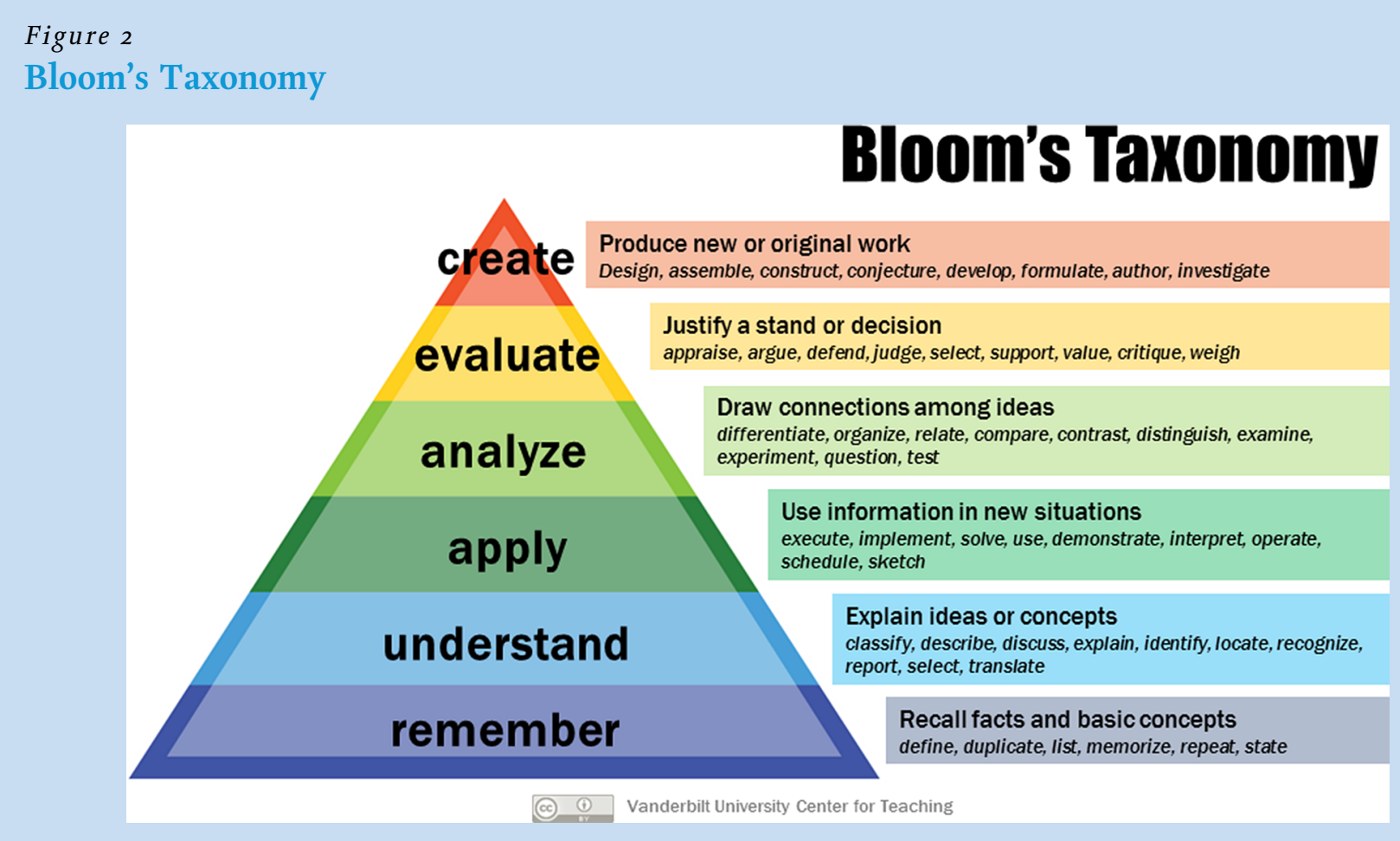

designs must connect the cognitive dimensions (i.e., foundational knowledge, application, and learning how to learn) and the affective dimensions (i.e., caring, human dimension, and integration throughout their life). Fink's framework holds that learning designs are most effective when they engage students in the affective and cognitive dimensions as well as the dimensions within each category. The open-inquiry course design accomplishes that.

On the cognitive side, open-inquiry course designs place the third cognitive dimension, learning how to learn, as the primary learning objective. Students focus on this dimension weekly as they experience the class they designed, reflect on its effectiveness, design a new learning experience for the next week, and engage in their new experience-effectively following Kolb's (1984) experiential learning cycle weekly throughout the semester. ${ }^{2}$

Through their reflective nature, open-inquiry course designs also facilitate learning about oneself (i.e., the human dimension). Students come to understand their individual strengths and weaknesses and how those manifest in team settings (Yorio and Ye 2012). Many instructors want their students to move toward a growth mindset (Dweck 2000; 2007). The frequent and consistent reflection on what they are learning, what they are missing, what was effective and productive, what was ineffective and unproductive, and what they and others are still confused about requires students to cultivate a growth mindset and a tolerance for nonlinear learning.

Open inquiry also incorporates the affective dimensions of learning. It includes caring as a legitimate and important aspect of learning-and one that many employers value as well (Miller, Wesley, and Williams 2012). Students choose their topics based on the values with which they enter the class. In pursuing the topics, they develop new values, perspectives, and respect for the communities engaged in the problems they address. This, in turn, increases their learning because student learning increases when students are emotionally engaged in the topic (Immordino-Yang 2015).

Finally, open-inquiry course designs help students grow because the design is explicitly constructivist. These course designs require students to construct both the method and the results of the learning in which they engage (Jonassen 1999; Kritt 2018). The design purposefully disrupts students' implicit idea that their professor is the source of learning. Indeed, in openinquiry course designs, students may view their professors as "refusing to do their job." By disrupting a dynamic that students are not aware of, the open-inquiry course design enables an important developmental leap, moving them from one idea of how learning occurs (i.e., by outside figures telling them about facts) to another (i.e., in which students generate the learning). If our goal is to educate students to engage as policy analysts in the complex problems of modern life, it is a journey worth facilitating (Kegan 1994).

\section{WHEN IS OPEN INQUIRY A GOOD FIT FOR PUBLIC POLICY CLASSROOMS?}

Open-inquiry course designs can generate important learning for both students and faculty, but this learning is not always easy. It is important to consider the right circumstances to employ this course design.

\section{Student Learning}

Open-inquiry course designs can be an ideal fit for our classrooms when they meet our learning goals. Nearly every course requires students to learn foundational knowledge about a new area and to engage in application by completing assessments in which they apply skills and knowledge. These are necessary but not sufficient curricular learning goals if we are to train students to flourish as 
Figure 3

Fink's Taxonomy of Learning

"I defined learning in terms of change." L. D. Fink

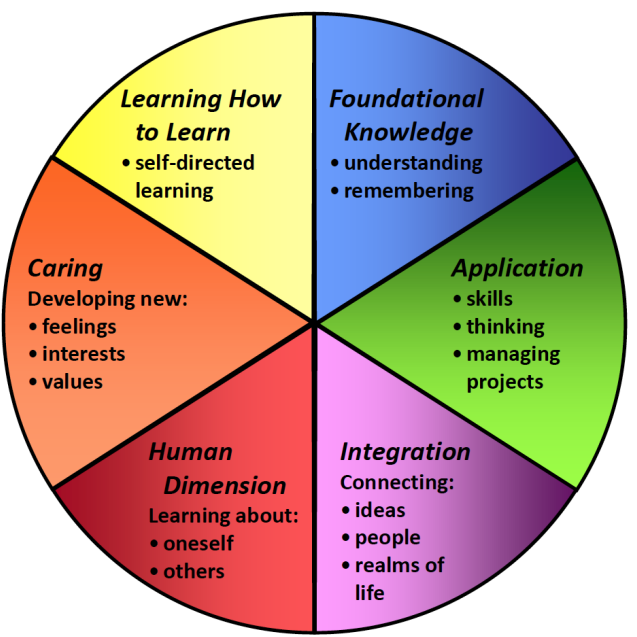

(C2003 L. Dee Fink, Creating Significant Learning Experiences

policy makers. Our students will enter complex policy environments in which problems are unstructured and it is unclear how stakeholders will identify either the problem or the solutions. These "swamp" issues require a distinct type of learning for both our students and the communities mired in them (Heifetz 1998; Schall 1995). For students entering these situations after graduation, they must learn how to learn in the face of confusion.

The confusion and frustration created in the initial stages of the open-inquiry process are a feature, not a bug. Learning how to learn is difficult. If thinking is famously difficult, then asking students to think about their thinking is even more difficult. To effectively learn how to learn in both our classes and across the arc of a career, both faculty and students must intentionally focus on this dimension of learning. Open-inquiry course designs are a particularly effective tool to help both parties keep learning how to learn at the forefront of the course. about but do not understand well. In the process of engaging in the projects, their values often evolve. Meeting the people and communities affected by public policies can alter what students value and profoundly shift their interests. Engaging in reflective practice helps students to connect their learning with the communities and values that motivated them to enroll in our programs, moving them to consider how they will apply this learning following graduation (Blount 2006).

As students integrate material in open-inquiry courses, they often learn concepts covered in other classes more profoundly. They frequently experience curricula in a piecemeal fashion, with a methods class here and a politics class there. Open inquiry creates space for students to integrate learning across courses. With open space in the schedule for them to learn as they need to, students may notice, for example, that their group processes are suboptimal, with little being accomplished and intragroup conflict about that paralysis. A social-psychology lesson on group dynamics from a previous semester is revisited and relearned. Students choose to learn the material again and process it in a new, more developed way-one that is more likely to be employed in the future (Perkins and Salomon 2012).

Finally, open inquiry has the potential to facilitate a different type of relationship between students and professors, one that moves students into a more collaborative role than a typical classroom. As students co-create learning with their professors, they begin the process of entering into a community of practice (Hansman 2001). This is the process of becoming a professional policy analyst.

Open-inquiry classrooms, like other experiential courses, become identity workspaces where students re-envision themselves, moving from viewing themselves as a student to a fellow collaborator. This is a key step toward the role of independent analyst that they will soon embrace fully after graduation (Petriglieri and Petriglieri 2010).

\section{Professor Learning}

There are benefits to instructors using open-inquiry course designs as well. The first and perhaps the most surprising benefit for me has been learning about my students. Their revealed preferences for topics taught me about their values. As we co-designed the class periods, I learned about their growth edges. For example, when I

\section{If thinking is famously difficult, then asking students to think about their thinking is even more difficult. To effectively learn how to learn in both our classes and across the arc of a career, both faculty and students must intentionally focus on this dimension of learning.}

Students who understand how to learn in unstructured situations have a better chance at making progress on swamp issues. They can reflect on and understand their own confusion and endure ambiguity instead of leaping to convenient but unsound conclusions. Their experiences enable them to have greater empathy and compassion for stakeholders who have been unable to solve the problems in which they are enmeshed (Parks 2005).

Open-inquiry course designs also increase student engagement and student learning by engaging the affective dimensions of learning. Students often select policy problems that they care asked students to make telephone calls to schedule slots during our site visit to the state capitol, they struggled. As a former legislative staffer, I did not anticipate that interacting with legislative offices on the telephone would be as challenging as it was (although scholars in other fields would have been less surprised by this dynamic) (Robinson and Reid 2007; Turkle 2015). Similarly, I could not have articulated their deep desire for training in public speaking, graphic design, interviewing, and other skills. I learned about them and the gaps in our curriculum that I would never have known if I had established the schedule. 
Second, I learned to care more for my students than I had before. Seeing their personhood so fully connected me to them in ways I had not anticipated. In choosing the projects, I learned more about what motivated my students: their values and their communities. Every week, I learned more about their growth edges as we co-created a plan to work on together. These two elements made their reflective papers extraordinarily personal and taught me more about the student population I was teaching in the first semester at my new institution than I learned in three years at my previous one.

Third, my substantive knowledge increased significantly. Students chose topics in which I was not an expert. They taught me about the problems, the actors involved, and the processes through which policy moves. Using the open-inquiry course design described in the next section, four teams of students investigated pressing policy problems around the state. I ran the class and supported their efforts while also learning alongside them.

\section{WHAT ARE THE DESIGN PRINCIPLES FOR OPEN-INQUIRY COURSES?}

Open-inquiry courses challenge students in unexpected ways. Students usually think of challenging courses as those that require them to master a more complex version of a defined task: "First I learned linear-regression models; now I am learning structuralequations models." Open inquiry asks students to exercise autonomy over their learning in ambiguous situations: to make decisions, walk down dead-end paths, and muddle through. In this process, students are asked to learn how to learn, to bring their whole person to the classroom when they are frustrated, and to reflect on themselves as well as the material. For students to learn from this frustration-and not only despite it-it is important to create a course design that matches these challenges with supports. and choose to leave the course or disengage from the learning process.

\section{Inhabit Multiple Roles as the Instructor}

The challenges of open-inquiry course designs require instructors to support student learning by inhabiting different roles-each with its own challenges, each of which must be fulfilled for the promise of open inquiry to be realized. Inhabiting these roles is a challenge because they require different skills that require us to relate to students by inhabiting roles that challenge the defaults of what a professor "should" be in the classroom (O'Brien 2019).

\section{Coach}

Learning how to learn is both rewarding and frustrating for students. Students often need faculty guidance to learn through and from the frustrations they experience. Some activities that students plan will be disappointing. Some learning will be difficult without expert instruction. Thinking about how to make progress on a project in which the professor is not an expert is difficult. The instructor as coach can add value by reorienting students in their low moments to the multiple purposes of the course design. Instructors can remind students of the realistic nature of learning without a syllabus in the workplace. They can help students name the learning that is happening through the ambiguity and challenge. We can be open about our own frustrations in the moment and how we have faith in the process because we have seen other students succeed in these situations.

\section{Fellow Learner}

Another powerful role that instructors assume is that of fellow learner. Often this role is invigorating. Learning about new substantive topics is energizing. Interacting with student-sponsored speakers broadens our networks. However, taking the role of

\section{Open inquiry asks students to exercise autonomy over their learning in ambiguous situations: to make decisions, walk down dead-end paths, and muddle through.}

\section{Learning How to Learn in the Learning Design as an Explicit Learning Objective}

From the first day of class, students need to understand that the contingent nature of what happens week to week is purposeful. The autonomy they are given over the learning will challenge them, and it is important to talk explicitly about those inevitable challenges and the supports in this process.

For some students, the lack of structure immediately strikes them as exciting. They enjoy the variability and autonomy that the course design allows. Other students view the variability and autonomy of the classroom experience with skepticism. They may ask why the professor is not "teaching" like their other professors. For them, the open-inquiry course design violates their unexamined assumptions that knowledge and learning come from instructors (Perry 1990). This assumption must be addressed directly so that the open-inquiry framework can help move students along their developmental trajectory.

Sometimes talking openly about this dynamic is enough; sometimes it is helpful to frame these discussions explicitly in the teaching and learning literature. If their skepticism is not engaged, then students can be frustrated by the course design fellow learner also requires humility. The expert role is a powerful norm created during a lifetime of schooling by students and faculty. Inhabiting a role as fellow learner implicitly communicates that the instructor does not have all the answers. When students rave about the applicability of skills that other faculty have taught them, open-inquiry instructors can feel diminished. It can be difficult to watch a student-run skill session engage students more than yours. Hearing my students talk about their growth edges has led to some uncomfortable realizations about the limitations of the programs that I helped design.

In these moments of discomfort, the challenge to open-inquiry instructors is to step into rather than away from the discomfort. Learning is challenging. One of the most helpful things instructors can do for their students is to think out loud in real time about difficult problems, whether pedagogical or substantive (Boice 2000). Students learn what learning realistically looks like as they watch instructors struggle in the moment to learn, be disappointed, and still move forward. Perhaps our greatest opportunity to shift students into a growth mindset is to be a case-in-point example ourselves. Learning publicly is one of the most powerful teaching tools at our disposal. 


\section{Adviser}

Instructors serve as project advisers helping students to make wise decisions. Strategic decisions about whether work products will focus on budget trends, legislative background, or cross-state comparisons are often something that students have little ability to judge wisely. Alternately, a student selected to lead a skills session may have a skill that other students want to learn from but has little idea how to teach in a college classroom. Guidance in these situations can make a significant difference in which facts, policy processes, and skills students learn and the usefulness of their final products for external audiences.

\section{Expert}

Instructors occasionally may add value by stepping into the role of professor. Students may ask instructors to lecture as a subjectmatter expert. If students identify a gap in their own knowledge, the instructor may be the right person to fill it. Open inquiry does not preclude instructors from conveying expert knowledge; the challenge is to ensure that a one-off performance does not revert toward a standard course design.

\section{Learning Designer and Evaluator}

Like all courses, instructors need to function as learning designers, choosing the open-inquiry method, setting the scope of inquiry appropriately, and creating an assignment structure. Instructors also are responsible for evaluating student learning. For openinquiry course designs to succeed, instructors must maintain their authority over these crucial tasks.

\section{Create Structures that Facilitate Learning from Ambiguity and Frustration}

Learning through ambiguity and frustration is difficult so it is important to create structures that help students learn to make sense of their learning.

\section{Establish Clear and Set Deliverables}

Although open inquiry is purposefully agnostic at the beginning of the course about what will happen during each week, students need to see a clear, scaffolded set of deliverables distributed throughout the semester. Students need to plan their workload each week and during the semester. Regular work products pace the progress through the learning. They also give professors regular opportunities to provide feedback to students about their understanding of the problem as well as their weaknesses.

\section{Engage in an Ongoing Conversation with Students about Their Experiences}

Students need to engage in continuing conversation during the semester about how they are learning and what they are learning about their learning at the class level, project-group level, and individual level. At the class level, the professor must create space for these conversations during class. For example, when a guest speaker makes a presentation, the professor must reserve time afterwards for students to process the conversation. Did we ask the questions we wanted or did the politician steer the conversation toward safe topics? What could we have done differently? An hour of experience will easily generate 15 to 30 minutes of well-structured group reflection and will pay dividends for student learning.
In addition to ongoing in-class conversations, formative assessment happens at both the project-group and individual levels. First, weekly meetings with project leaders can ensure that everyone is moving together in the same direction. Team leaders can ask instructors questions about projects, convey concerns, and plan class time. This facilitates buy-in from the other students and keeps frustration at a productive level, fostering a collaborative rather than oppositional spirit.

Students receive instructor feedback weekly through update memos that answer the following three questions: What did I do last week? What will I do this week? What help do I need this week from my professor? Weekly memos help the instructor formatively engage individual students. In my experience, it is important to have all three avenues open.

Finally, for the power of open-inquiry learning to be realized, students must reflect before, during, and after the semester concludes. Comprehensive written reflections at key moments in the course are an important formative tool (see online appendix A for an example). For some students, the reflective approach is easily understood. Others may need to see evidence of how it will increase their learning to accept it. The burgeoning literature on metacognition all describe the same simple framework: experience + reflection $=$ growth .

\section{Be Wise about Situational Factors}

Open-inquiry courses exist inside institutions with unique situational factors that create the boundaries of what is and is not possible (Fink 1984). In reflecting on the success of the course at my institution, three situational factors are highlighted. First, I benefited from having a 20-student elective course with primarily second-year Master of Public Policy (MPP) students. They already had many skills needed to engage their policy problems, and the small class size provided the time I needed to invest in each project and student. Second, the administration was supportive of my course design. Taken out of context, a course syllabus that largely reads "TBD" might not impress the deans. I was fortunate to have their support when I proposed the idea. Third, the focus on statelevel issues gave the students access to policy makers and site visits in ways that might not be possible at the international or federal level, or even in larger states.

\section{WHAT IS A CONCRETE EXAMPLE OF AN OPEN-INQUIRY COURSE?}

My open-inquiry experience began with an elective course titled "Virginia Politics and Policy" (VPP). Offered primarily to secondyear MPP students, VPP is the only course in our program focusing primarily on state government. As an elective, the course is capped at 20 students. Multiple students had interned in the state capital or were working with Virginia clients for their capstone projects. Personal interest was high. The course was pitched to students specifically as an open-inquiry course. In fact, although the course schedule described a carefully scaffolded set of work products, the topics for each class read simply "TBD." ${ }^{3}$

\section{Project-Selection Process}

During the first class meeting, I divided the students into groups based on which region of Virginia they wanted to study during the semester. With a population of 8.5 million people, Virginia has remarkable regional diversity, ranging from some of the nation's 
poorest counties in the far-southwest to some of the wealthiest in the DC suburbs. Returning the second day, regional groups presented three policy problems to the class that they were interested in studying during the semester. They discussed the importance of the topic, accessibility to public officials engaged in the topic, whether the topic was currently on the political agenda, and their ability to engage meaningfully within the confines of a semester. The presenters then fielded questions from other students, and the class (myself included) voted on which of the three options the group would study. Because the rest of the class would be learning about the semester topic, they deserved to have input.

\section{Creating Class Content}

The content for the remaining class periods depended on the needs of each team, the needs of the class as a whole, and the learning opportunities presented to us. Team leaders met with me every Monday to consider which content and activities would make the best use of class time on Thursday, when class was in session. Team leaders came to the Monday meetings with ideas from their group. We maintained a running list of ideas that we revisited each week alongside the calendar for the remainder of the semester. Following is a sampling of the ways that students chose to productively use class time.

\section{Discussion of Background/Overview Readings}

Early in the course, students often decided that they needed some broad background information about Virginia's history and system of government to help them understand their policy challenges. As relatively new arrivals to a nearly 250 -year-old state, they recognized that they had much to learn about how history, political institutions, political dynamics, economic trends, and regional identities affected their problem and those trying to respond to it. Readings include classics such as the Virginia chapter of Key's (1949) Southern Politics, practical textbook selections on the mechanics of state government (Peaslee and Swartz 2013), popular-press accounts of massive resistance throughout Virginia to integrating the public schools (Green 2016), and coverage from regional and national newspapers. response, they began to schedule class time to remedy those gaps. Examples include a law professor talking about understanding legal code, a journalist holding a workshop about interviewing lawmakers, and a community organizer holding a workshop on public speaking.

\section{Site Visits}

The only day scheduled in the syllabus at the beginning of the semester was a visit to the state capital. Using my relationships, I bookended the day with a visit to the speaker's office and a meeting at the governor's office. The remaining time was at the discretion of the students. They decided which legislative offices to connect with and which agency personnel would be best to meet with in person.

Additionally, each group had the opportunity to propose a site visit for the class. One memorable site visit was to a local whiskey distillery. The owner was part of an interest-group coalition working to change alcohol taxes. It was striking for many of the liberalleaning students to have a business owner walk them through how government regulations impacted his facility.

\section{DISCUSSION}

During the various semesters that I have taught this class, this open-inquiry course design has generated significant student learning across each of Fink's (2013) dimensions. Although evaluations are imperfect measures of student learning, the written responses are illuminating. Two themes emerge.

The first theme is that students report that they are learning how to learn. Almost all of them write in their reflections and in their course evaluations how the open-inquiry course design challenged them to think explicitly about this theme. Students speak explicitly about the ambiguity of the course structure and how it forced them to think about their learning. They often use frustration to talk about this theme, but almost all of them move through the frustration toward success and resolution. They ultimately are not frustrated and they reflect on the role that the frustration played in their learning.

\section{Students speak explicitly about the ambiguity of the course structure and how it forced them to think about their learning. They often use frustration to talk about this theme, but almost all of them move through the frustration toward success and resolution.}

\section{Guest Speakers}

As students began to investigate their policy problems, they quickly encountered individuals who could shed light on important aspects of their problem. As each group scheduled interviews outside of class, team leaders looked for opportunities to bring stakeholders into class. If stakeholders could clarify a political or policy process that touched on more than one group's project, they became a candidate as an in-class speaker. Subject-matter experts, agency personnel, interest groups, politicians, and others visited our class.

\section{Skill Development}

As the teams worked, students became cognizant of what missing skills were keeping them from creating their work products. In
Students mention how at the beginning of the course, they were frustrated by the ambiguity inherent in the design. They discuss how they had to create a plan, implement it, learn from the successes and the failures, and then create another plan about what to learn next. Many students speak of their experiences using the metacognitive language of the course: how the metacognitive themes shaped their learning about their projects and how it shaped their thinking about learning itself.

The second theme is the students' appreciation for the experiential aspects of the course design. Their learning is driven by their interest in the topics they selected at the beginning of the course. Those topics, in turn, motivate them to learn the substantive knowledge (knowledge) necessary to understand and write about the topics in a format that will make an impact (application). The 
projects they produce often are substantially better than those in similar problem-based learning-design courses in our curriculum. Moreover, these work products are regularly distributed to the policy makers with whom students interacted during the semester. On more than one occasion, the groups have been asked to give presentations or participate in the policy process moving forward.

One reason that students are offered these positions is that they have knowledge about and experience with stakeholders, processes, and problems at the state level and they have the skills needed to make progress on these policy problems. Employers value the skills that students develop during the course: they better understand how to structure a major project, interview stakeholders, and conduct a site visit. Another reason is that students apply for state-level jobs. Students report choosing to apply because the course shaped their values. At the end of the semester, many students report that they value more the work of state government and that they are more sympathetic toward elected officials-many even report that they may consider running for elected office.

At the end of the semester, many students report that it is one of the most meaningful courses in their graduate career. Students express gratitude for the agency that they are granted in choosing projects that mattered to them and for the supporting assignment structures and feedback they received on a weekly basis. They report that it was work they were glad to do.

\section{CONCLUSION}

After 15 years of teaching at the university level, I have found that my courses have evolved slowly toward the principles embedded in open-inquiry course designs: student choice, engaging students directly about their learning process, engaging them across multiple dimensions of learning, and evidence-based learning practices. Through the years, I have ceded increasingly more of the learning to the students. As a graduate student in my twenties, I mostly lectured. As a professor in my forties, I work to give away as much of the learning to the students as possible. My theory of student learning has evolved from not having one, to learning as knowledge transfer, to seeing learning as a transformational process achieved by engaging students on multiple dimensions, to now exploring models of human development that encompass professional growth affecting every dimension of the life of a student.

The more I have watched former students progress through careers in the public sector, the more I have found that growth is necessary across all of the dimensions-cognitive and affectivefor students to succeed. In our programs, students are developing both skills and identities. We are creating structures through which they can grow to become professional problem seekers and solvers who can learn effectively without professors guiding them.

Of course, open inquiry is not the only course design that can help students grow. It is not the appropriate choice for many courses in which a specific skill set must be mastered. The theories of teaching and learning that undergird this approach do not demand that every class use an open-inquiry course design. Depending on the situation and the goals, open-inquiry course design can generate learning that is significant for both professors and students. It is a unique design and one that I am grateful to have in my toolbelt.

\section{ACKNOWLEDGMENTS}

I thank Dorothe Bach, Michael Palmer, and Lindsay Wheeler from the Center for Teaching Excellence at UVA for their encouragement in pursuing the open-inquiry approach as a means of enhancing student learning. I also thank Timothy O’Brien, Daniel Player, an anonymous reviewer, and the editors at $P S$ for their comments, all of which greatly improved this article.

\section{SUPPLEMENTARY MATERIALS}

To view supplementary material for this article, please visit http:// dx.doi.org/10.1017/S1049096520000475."

\section{NOTES}

1. Student learning likely will increase as the new tools for measuring effective teaching in STEM disciplines filter into our programs and help us understand which evidence-based practices actually are being used in them (Eddy, Converse, and Wenderoth 2015; Palmer, Bach, and Streifer 2014; Smith et al. 2013; Stains et al. 2018).

2. In Kolb's (1984) experiential learning cycle, students engage in a concrete learning experience, reflect on the successes and failures, form hypotheses about the causes of those successes and failures, and then engage actively in experimentation to determine if they have learned successfully.

3. The students produced an issue brief, stakeholder analysis, legislative and regulatory history, two-page report, final report (10 single-spaced pages), and final presentation.

\section{REFERENCES}

Airasian, Peter W., Lorin W. Anderson, and David Krathwohl (eds.). 2000. A Taxonomy for Learning, Teaching, and Assessing: A Revision of Bloom's Taxonomy of Educational Objectives, Abridged Edition. New York: Pearson.

Amyot, Robert P. 2014. "Is It Better to Be Feared Than Loved? Investigating the Efficacy of Different Teaching Methods on the Learning of Specific Content." PS: Political Science \& Politics 47 (4): 855-61.

Bardach, Eugene, and Eric M. Patashnik. 2015. Practical Guide for Policy Analysis: The Eightfold Path to More Effective Problem Solving. Fifth edition. Los Angeles: CQ Press.

Bloom, Benjamin Samuel. 1956. Taxonomy of Educational Objectives: The Classification of Educational Goals. New York: Longmans, Green \& Co.

Blount, Alma G. 2006. "Critical Reflection for Public Life: How Reflective Practice Helps Students Become Politically Engaged.” Journal of Political Science Education 2 (3): 271-83.

Boice, Robert. 200o. Advice for New Faculty Members: Nihil Nimus. Boston: Allyn \& Bacon.

Cooley, Valerie, and Andrew Pennock. 2015. "Teaching Policy Analysis Through Animated Films: A Mickey Mouse Assignment?" PS: Political Science \& Politics 48 (4): 601-6o6.

Cross, Jeanne, and Nancy Grant. 2006. "Teaching MPA Internships Built on Reflection in Practice." Journal of Public Affairs Education 12 (1): 19-31.

Dweck, Carol. 2007. Mindset: The New Psychology of Success. New York: Ballantine Books.

Dweck, Carol. 20oo. Self-Theories: Their Role in Motivation, Personality, and Development. Philadelphia: Psychology Press.

Eddy, Sarah L., Mercedes Converse, and Mary Pat Wenderoth. 2015. "PORTAAL: A Classroom Observation Tool Assessing Evidence-Based Teaching Practices for Active Learning in Large Science, Technology, Engineering, and Mathematics Classes." CBE: Life Sciences Education 14 (2): ar23.

Fink, L. Dee. 1984. “The First Year of College Teaching.” New Directions for Teaching and Learning 17:111-19.

Fink, L. Dee. 2013. Creating Significant Learning Experiences: An Integrated Approach to Designing College Courses. Second edition. San Francisco: Jossey-Bass, Inc.

Freeman, Scott, et al. 2014. "Active Learning Increases Student Performance in Science, Engineering, and Mathematics." Proceedings of the National Academy of Sciences 111 (23): 8410.

Green, Kristen. 2016. Something Must Be Done about Prince Edward County: A Family, a Virginia Town, a Civil Rights Battle. New York: Harper Perennial.

Hacker, Douglas J., John Dunlosky, and Arthur C. Graesser. 1998. Metacognition in Educational Theory and Practice. Philadelphia: Routledge. 
Hansman, Catherine A. 2001. "Context-Based Adult Learning." New Directions for Adult and Continuing Education 89:43-52.

Heifetz, Ronald. 1998. Leadership Without Easy Answers. Cambridge, MA: Harvard University Press.

Immordino-Yang, Mary Helen. 2015. Emotions, Learning, and the Brain: Exploring the Educational Implications of Affective Neuroscience (The Norton Series on the Social Neuroscience of Education). New York: W. W. Norton \& Company.

Jonassen, David H. 1999. “Designing Constructivist Learning Environments.” Instructiona Design Theories and Models: A New Paradigm of Instructional Theory 2:215-39.

Kegan, Robert. 1994. In Over Our Heads: The Mental Demands of Modern Life. Cambridge, MA: Harvard University Press.

Key, V.O. 1949. Southern Politics in State and Nation. Knoxville: University of Tennessee Press.

Kolb, David A. 1984. Experiential Learning: Experience as the Source of Learning and Development. Englewood Cliffs, NJ: Prentice-Hall.

Kritt, David W. 2018. Constructivist Education in an Age of Accountability. New York: Springer Publishing.

Major, Clair H., and Betsy Palmer. 2001. "Assessing the Effectiveness of ProblemBased Learning in Higher Education: Lessons from the Literature." Academic Exchange Quarterly 5 (1): 1-2.

McInerney, Chris, and Maura Adshead. 2013. "Problem-Based Learning and Civic Engagement: Shifting the Focus of Learning in Public Policy Education." PS: Political Science \& Politics 46 (3): 630-36.

Miller, Toyah L., Curtis L. Wesley, and Denise E. Williams. 2012. "Educating the Minds of Caring Hearts: Comparing the Views of Practitioners and Educators on the Importance of Social Entrepreneurship Competencies." Academy of Management Learning \& Education 11 (3): 349-70.

O'Brien, Timothy. 2019. "When Your Job Is Your Identity, Professional Failure Hurt More." Harvard Business Review. Available at https://hbr.org/2019/06/how-weconfuse-our-roles-with-our-self.

Palmer, Michael S., Dorothe J. Bach, and Adriana C. Streifer. 2014. "Measuring the Promise: A Learning-Focused Syllabus Rubric." To Improve the Academy 33 (1):14-36

Palmer, Michael S., Adriana C. Streifer, and Stacy Williams-Duncan. 2016. "Systematic Assessment of a High-Impact Course Design Institute." To Improve the Academy 35 (2): 339-61.

Parks, Sharon Daloz. 2005. Leadership Can Be Taught: A Bold Approach for a Complex World. Boston: Harvard Business Review Press.

Peaslee, Liliokanaio, and Nicholas J. Swartz. 2013. Virginia Government: Institutions and Policy. Washington, DC: CQ Press.

Pennock, Andrew. 2011. "The Case for Using Policy Writing in Undergraduate Political Science Courses.” PS: Political Science \& Politics 44 (1): 141-46.

Pennock, Andrew. 2018. The CQ Press Writing Guide for Public Policy. Washington, DC: CQ Press.
Perkins, David N., and Gavriel Salomon. 2012. "Knowledge to Go: A Motivational and Dispositional View of Transfer." Educational Psychologist 47 (3): 248-58.

Perry, William G. 1990. Forms of Intellectual and Ethical Development in the College Years: A Scheme. Jossey-Bass Higher and Adult Education Series. San Francisco: Jossey-Bass, Inc.

Petriglieri, Gianpiero, and Jennifer Louise Petriglieri. 2010. "Identity Workspaces: The Case of Business Schools." Academy of Management Learning \& Education 9 (1): 44-6o.

Pugalee, David K. 2001. "Writing, Mathematics, and Metacognition: Looking for Connections Through Students' Work in Mathematical Problem Solving." School Science and Mathematics 101 (5): 236-45

Robinson, Catherine M., and Peter Reid. 2007. "Do Academic Enquiry Services Scare Students?" Reference Services Review 35 (3): 405-24.

Schall, Ellen. 1995. "Learning to Love the Swamp: Reshaping Education for Public Service." Journal of Policy Analysis and Management 14 (2): 202-20.

Schoenfeld, Alan H. 1992. "Learning to Think Mathematically: Problem Solving, Metacognition, and Sense Making in Mathematics." In Handbook of Research on Mathematics Teaching and Learning: A Project of the National Council of Teachers of Mathematics, ed. Douglas A. Grouws, 334-70. New York: Macmillan Publishing Co., Inc

Smith, Michelle K., Francis H. M. Jones, Sarah L. Gilbert, and Carl E. Wieman. 2013 "The Classroom Observation Protocol for Undergraduate STEM (COPUS): A New Instrument to Characterize University STEM Classroom Practices." CBE: Life Sciences Education 12 (4): 618-27.

Stains, Marilyne, et al. 2018. "Anatomy of STEM Teaching in North American Universities." Science 359 (6383): 1468-70.

Tobias, Sigmund, and Howard T. Everson. 2009. "The Importance of Knowing What You Know: A Knowledge-Monitoring Framework for Studying Metacognition in Education." In Handbook of Metacognition in Education, ed. Douglas J. Hacker, John Dunlosky, and Arthur C. Graesser, 107-27. Philadelphia: Routledge/Taylor \& Francis Group. Available at http://www.taylorfrancis.com.

Tolman, Anton O., and Janine Kremling. 2016. Why Students Resist Learning: A Practical Model for Understanding and Helping Students. Sterling, VA: Stylus Publishing, LLC.

Turkle, Sherry. 2015. Reclaiming Conversation: The Power of Talk in a Digital Age New York: Penguin Press.

Vining, Aidan R., and David L. Weimer. 2002. "Introducing Policy Analysis Craft: The Sheltered Workshop." Journal of Policy Analysis and Management 21 (4): 697-707.

Williamson, Jonathan, and Alison S. Gregory. 2010. "Problem-Based Learning in Introductory American Politics Classes." Journal of Political Science Education 6 (3): $274-96$.

Yorio, Patrick L., and Feifei Ye. 2012. "A Meta-Analysis on the Effects of ServiceLearning on the Social, Personal, and Cognitive Outcomes of Learning." Academy of Management Learning \& Education 11 (1): 9-27. 